\title{
Technique of war crimes regulation in the 1960 Criminal Code of the RSFSR
}

\author{
Yu. O. Goncharova ${ }^{1}$
}

${ }^{1}$ P. G. Demidov Yaroslavl State University, 14 Sovetskaya str., Yaroslavl 150003, Russian Federation

DOI: $10.18255 / 1996-5648-2021-4-574-581$

Research article

Full text in Russian

The article analyses the technique of regulating war crimes in the Criminal Code of the RSFSR of 1960. The author notes the need for a retrospective analysis of the legislative technique of war crimes in order to consider this type of crime most holistically. Despite the existence of discussions in the theory of criminal law about the concept of legislative technique and the elements included in it, the author interprets legislative technique as a set of means and techniques used to give the content of legislative norms an appropriate form. This article also notes the need to distinguish the category of "war crimes» in the criminal legislation of the Russian Federation, as this term is widespread in international criminal law. The author attributes the following provisions of the Criminal Code to war crimes: Article 356 ( «Application of prohibited means and methods of warfare»), Article 357 («Genocide») and Article 359 («Menary»). The author conducts a comparative analysis of the legislative technique of the norms on criminal liability for war crimes of the current criminal legislation and criminal legislation of the Soviet period. From the analysis, some features of the technique of regulating war crimes of the Soviet period are revealed, namely: a) most of the elements of war crimes were designed using the casual reception of legislative equipment; b) the Soviet legislator used a direct way of presenting the norms without applying references; c) the note was used to build some formulations of war crimes, but did not This paper also examines a number of imperfections in the technique of regulating war crimes in the 1960 Criminal Code.

Keywords: Criminal law; 1960 Criminal Code of the RSFSR; war crimes; regulatory technique; legislative equipment; means of legislative equipment; methods of legislative equipment

INFORMATION ABOUT AUTHORS

Goncharova, Yulia O. $\begin{aligned} & \text { E-mail: julygoncharova97@yandex.ru } \\ & \text { Postgraduate }\end{aligned}$

This is an open access article under the CC BY license (https://creativecommons.org/licenses/by/4.0/) 


\section{Техника регламентации}

военных преступлений

в Уголовном кодексе РСФСР 1960 года

\section{Ю. О. Гончарова ${ }^{1}$}

${ }^{1}$ Ярославский государственный университет им. П. Г. Демидова, ул. Советская, 14, Ярославль, 150003, Российская Федерация

DOI: $10.18255 / 1996-5648-2021-4-574-581$

УДК 343.337 .4

Научная статья

Полный текст на русском языке

В статье анализируется техника регламентации военных преступлений в Уголовном кодексе РСФСР 1960 года. Автор отмечает необходимость ретроспективного анализа законодательной техники военных преступлений для наиболее целостного рассмотрения данного вида преступлений. Несмотря на наличие дискуссий в теории уголовного права относительно понятия законодательной техники и элементов, входящих в нее, автором трактуется законодательная техника как совокупность средств и приемов, используемых для придания содержанию законодательных норм соответствующей фрормы. Отмечается необходимость выделения категории «военные преступления» в уголовном законодательстве Российской Федерации, так как данный термин широко распространен в международном уголовном праве. Автор относит к военным преступлениям следующие нормы УК РФ: статью 356 («Применение запрещенных средств и методов ведения войны»), статью 357 («Геноцид») и статью 359 («Наемничество»). Проводится сравнительный анализ законодательной техники норм об уголовной ответственности за военные преступления действующего уголовного законодательства и уголовного законодательства советского периода. Выявляются некоторые особенности техники регламентации военных преступлений советского периода: а) большинство составов военных преступлений сконструированы с использованием казуистического приема законодательной техники; б) советский законодатель использовал прямой способ изложения норм, не применяя отсылок; в) прием «примечание» был использован для построения некоторых составов военных преступлений, однако не совсем оправдал себя. В статье также рассматривается ряд несовершенств техники регламентации военных преступлений в Уголовном кодексе 1960 года.

Ключевые слова: уголовное право; УК РСФСР 1960 года; военные преступления; техника регламентации; законодательная техника; средства законодательной техники; приемы законодательной техники

\section{ИНФОРМАЦИЯ ОБ АВТОРАХ} \begin{tabular}{l|l} 
Гончарова, Юлия Олеговна & $\begin{array}{l}\text { E-mail: julygoncharova97@yandex.ru } \\
\text { Аспирант }\end{array}$
\end{tabular}

(C) Гончарова Ю. О., 2021

Статья открытого доступа под лицензией CC BY (https://creativecommons.org/licenses/by/4.0/) 
Проблемы уголовной ответственности за военные преступления, на наш взгляд, одна из самых актуальных тем в доктрине уголовного права, и при этом наименее исследованная не только в настоящее время, но и на протяжении достаточно длительного исторического периода. Война - негативное явление, которое красной нитью тянется сквозь всю историю нашего государства. К сожалению, человечество регулярно погружается в военные конфликты разной интенсивности, которые сопровождаются большим количеством военных преступлений. Думается, что для более детального и глубокого рассмотрения ответственности за преступления, совершаемые во время военных действий, необходимо отправиться назад в прошлое, рассмотреть данный институт в историческом аспекте. В предлагаемой статье речь пойдет об Уголовном кодексе РСФСР (утв. ВС РСФСР 27.10.1960), и прежде всего о технико-юридических аспектах построения норм о военных преступлениях в указанном кодифицированном уголовно-правовом акте.

В первую очередь стоит отметить, что понимается под законодательной (юридической) техникой в уголовном праве. Ряд отечественных ученых при определении указанного института основное внимание уделяют практической разработанности ее основных приемов. Так, И. К. Ильин и Н. В. Морозов считают, что законодательная техника является «совокупностью определенных, выработанных опытом и проверенных практикой, приемов и методов работы по подготовке и изданию различных правовых актов нормативного и ненормативного характера» [1, с. 65-73]. По верному замечанию Д. А. Керимова, в законодательной технике тесно переплетаются элементы науки, практики и юридического мастерства [2, с. 52]. Поэтому при анализе конструирования уголовно-правовых запретов невозможно исключать фактор научной обусловленности технико-юридических приемов.

В науке уголовного права принято выделять следующие элементы законодательной техники: 1) средства, 2) приемы, 3) правила. Однако, на наш взгляд, не стоит выделять правила законодательной техники как самостоятельную единицу, так как они по своему существу «характеризуют использование технических средств и приемов, относящихся в основном к внешней форме» [3, с. $221 ; 4$, с. 77]. По существу, правила являются факультативным элементом технико-юридического инструментария правотворческого процесса.

Мы считаем, что законодательную технику следует определять как совокупность средств и приемов, используемых для придания содержанию законодательных норм соответствующей формы. Данная дефини- 
ция лаконична и в то же время отражает все сущностные характеристики определяемого понятия.

Остановимся для начала на средствах законодательной техники. Полагаем, что под средствами техники регламентации должны пониматься не явления или методы (способы), а нематериальные инструменты законодателя. В юридической литературе отсутствует единое мнение о круге таких средств. Однако мы считаем верным относить к содержанию такого элемента законодательной техники, как средства, следующие понятия: а) терминологию (языковые средства); б) презумпции; в) фрикции; г) юридические конструкции; д) символы; е) аксиомы. При этом не исключаем расширение данного списка, включения в него новых юридических понятий за счет развития теории уголовного права [5, с. 70].

Не уступает в актуальности и дискуссионности вопрос о приемах законодательной техники. Так, С. С. Алексеев предлагает выделять две группы приемов: а) по степени обобщения конкретных показателей абстрактный и казуистический; б) по способу изложения - прямой, отсылочный, бланкетный. Думается, что подобная классификация является оптимальной. В свою очередь, А. В. Иванчин под приемами понимает «способы построения нормативных предписаний, в том числе соединенные с использованием определенного средства» [6, с. 64]. $K$ их числу автор относит приемы примечания, дефиниции, непосредственно-определенный и ссылочный приемы. Полагаем, что наиболее правильным будет относить к приемам законодательной техники следующие элементы: а) абстрактный и казуистический (по степени обобщения конкретных показателей нормы) приемы; б) непосредственно-определенный (прямой), отсылочный и бланкетный (по способу изложения) приемы; в) прием - примечание.

Далее рассмотрим вопросы конструирования норм о военных преступлениях. Отечественная наука не имеет единого подхода к пониманию военных преступлений, а современное законодательство и вовсе не содержит это понятие, несмотря на то что словосочетание «военные преступления» повсеместно встречается в международных правовых актах. Перечень военных преступлений дается в статье 6 Устава Международного Военного трибунала для суда и наказания главных военных преступников европейских стран оси. Данный документ относит к военным преступлениям «убийства, истязания или увод в рабство или для других целей гражданского населения оккупированной территории; убийства или истязания военнопленных или лиц, находящихся в море; убийства заложников; ограбление общественной или частной собственности; бессмысленное разрушение городов или деревень; разорение, не оправдан- 
ное военной необходимостью, и другие преступления». Исходя из этого, наиболее удачное определение круга рассматриваемых посягательств со схожим групповым объектом предложено А. В. Наумовым [7, с. 603], Н. И. Ветровым [8, с. 436], А. А. Гравиной [9, с. 427]. Указанные ученые относят к военным преступлениям деяния, предусмотренные ст. 356 («Применение запрещенных средств и методов ведения войны»), ст. 357 («Геноцид») и ст. 359 («Наемничество») УК РФ.

Стоит отметить, что в истории уголовного права до принятия ныне действующего Уголовного кодекса РФ не упоминались составы военных преступлений в том виде, в каком они существуют сейчас. $K$ примеру, отсутствовала ответственность за геноцид и наемничество. В некоторых статьях, разбросанных по Уголовному кодексу РСФСР 1960 года, можно увидеть деяния, частично подпадающие под объективную сторону ныне действующей ст. 356 УК РФ «Применение запрещенных средств и методов войны». К таковым можно отнести ст. 67.1 «Применение биологического оружия», ст. 267 «Насилие над населением в районе военных действий», ст. 268 «Дурное обращение с военнопленными», ст. 269 «Незаконное ношение знаков Красного Креста и Красного Полумесяца и злоупотребление ими».

При детальном рассмотрении вышеуказанных статей можно сделать некоторые выводы. Во-первых, большинство составов военных преступлений сконструированы в УК РСФСР с использованием казуистического приема законодательной техники. Мы видим перечисление в законе всех максимально возможных действий, составляющих объективную сторону преступлений. Заметим, что в настоящее время законодатель при описании военных и иных международных преступлений в большей степени использует абстрактно-казуистический нормативный прием, перечисляя лишь несколько основных действий, составляющих объективную сторону, при этом оставляя перечень этих действий открытым.

Во-вторых, советский законодатель использовал прямой способ изложения норм, не применяя отсылок, как внешних, так и внутренних. В действующем Уголовном кодексе РФ законодатель, избегая громоздкие казуистичные диспозиции, старается применять по возможности бланкетный прием конструирования составов военных преступлений, используя отсылки к нормам международного права.

В-третьих, в статье 67.2 УК РСФСР 1960 года находится примечание-дефиниция, относящееся в том числе и к рассматриваемой нами статье 67.1. В данном примечании расшифровывается понятие биологического оружия. На наш взгляд, данная дефиниция не совсем удачна, так как в ней 
под биологическим оружием понимается не только само оружие (живые организмы, вирусы и т. д.), но и средства их доставки. Таким образом, происходит подмена понятий, так как средства доставки биологического оружия на понятийном уровне становятся самим биологическим оружием. В настоящее время аналогичная ст. 356 УК РФ не содержит такого приема законодательной техники, как примечание.

При анализе техники регламентации военных преступлений советского периода просматриваются некоторые недочеты и относительно средств законодательной техники. Так, например, ст. 267 УК РСФСР 1960 года называется «Насилие над населением в районе военных действий». В диспозиции данной статьи законодателем перечисляются действия, входящие в объективную сторону состава, а именно в понятие «насилие», для удобства правоприменения данной нормы. Однако, если посмотреть на данный перечень, то можно увидеть некую путаницу. Статья 267 выглядела следующим образом: Статья 267. Насилие над населением в районе военных действий: «Разбой, противозаконное уничтожение имущества, насилие, а равно противозаконное отобрание имущества под предлогом военной необходимости, совершаемые по отношению к населению в районе военных действий, - наказываются лишением свободы на срок от трех до десяти лет или смертной казнью».

В первую очередь бросается в глаза, что под насилием над населением понимаются в основном насильственные действия против собственности, а не в отношении населения. Разбой, уничтожение имущества, отобрание имущества - это все преступления, основным объектом которых являются имущественные отношения, а не личность, которая указывается в названии статьи. И лишь между этими действиями законодатель прописывает это «насилие», которое и остается нераскрытым.

Обратившись к толковому словарю С. И. Ожегова, мы видим, что под насилием понимается: 1) Применение gбизической силъ к кому-н. Акт насилия. Следъ насилия на теле. 2) Принудительное воздействие на кого-н., нарушение личной неприкосновенности. Н. над личностью. 3) Притеснение, беззаконие (книжн.). Произвол. [10, с. 711].

Таким образом, под насилием понимаются действия, направленные непосредственно к человеку, личности, и, следовательно, к насилию нельзя приравнивать разбой, уничтожение имущества и т. д. Следовательно, советский законодатель допустил серьезную ошибку в технике регламентации ст. 267 УК РСФСР.

Далее проанализируем ст. 268 УК РСФСР 1960 года. Она выглядела следующим образом: Статья 268. Дурное обращение с военнопленнъли: 
«а) Дурное обращение с военнопленными, имевшее место неоднократно, или сопряженное с особой жестокостью, или направленное против больных и раненых, а равно небрежное исполнение обязанностей в отношении больных и раненых лицами, на которых возложены лечение их и попечение о них, при отсутствии признаков более тяжкого преступления - наказываются лишением свободы на срок от одного года до трех лет;

б) дурное обращение с военнопленными без указанных отягчающих обстоятельств - влечет применение правил Дисциплинарного устава Вооруженных Сил СССР».

Рассматривая данную статью, обращаем внимание на то, что квалифицирующие признаки находятся в части первой, соответственно, основной состав находится в части второй. Налицо очередной сбой законодательной техники и правил дифференциации ответственности, поскольку квалифицированные составы должны размещаться после основных. Стоит отметить, что другие нормы УК РСФСР сконструированы технически более оптимально, что говорит не об общей негативной тенденции в процессе конструирования составов советского уголовного законодательства о военных преступлениях, а о наличии ошибки исключительно в рассматриваемом нами составе.

Также, на наш взгляд, пробел законодательной техники при описании деяния, закрепленного в данной статье, просматривается и в том, что законодатель не указал, что понимается под дурным обращением, сам же термин выглядит достаточно абстрактно, что позволяет предугадать необоснованно широкие границы его усмотрения в судебно-следственной практике исследуемого периода.

Таким образом, можно сделать вывод, что техника регламентации уголовной ответственности за военные преступления в УК РСФСР 1960 года страдала некоторыми нормативными пробелами. Во-первых, следует отметить достаточно узкие границы уголовно-правового регулирования в сравнении с международным криминальным правом. Во-вторых, на наш взгляд, недостатком является слабое использование бланкетного приема при обрисовке исследуемых норм. В-третьих, серьезным технико-юридическим сбоем считаем наличие в нормах о военных преступлениях абстрактных, неконкретизированных терминов, которые, очевидно, вызывали сложности в процессе квалификации.

\section{Ссылки}

1. Ильин И. К., Морозов Н. В. О форме и стиле правовых актов // Советское государство и право. 1960. № 12. С. 67-69. 
2. Керимов Д. А. Законодательная техника. М., 2000. 121 с.

3. Алексеев С. С. Государство и право: Начальный курс. М., 1993. 192 с.

4. Соловьев О. Г., Гончарова Ю. О. Дискуссионные аспекты определения перечня средств и приемов законодательной техники в правотворческом процессе // Вестник Ярославского государственного университета им. П. Г. Демидова. Серия Гуманитарные науки. 2021. Т. 15, № 1. С. 76-83.

5. Соловьев О. Г. Юридические символы как средства конструирования составов преступлений в сфере экономической деятельности (гл. 22 УК РФ) // Вестник Ярославского государственного университета им. П. Г. Демидова. Серия Гуманитарные науки. 2016. № 2. С. 69-72.

6. Иванчин А. В. Понятие техники построения уголовного законодательства // Дифференциация ответственности и вопросы юридической техники в уголовном праве и процессе: сб. науч. ст. / под ред. Л. Л. Кругликова. Ярославль: ЯрГУ, 2001. C. $63-71$.

7. Наумов А. В. Российское уголовное право: Курс лекций: в 3 т. Т. 3: Особенная часть. 6-е изд. М., 2018. 704 с.

8. Ветров Н. И. Уголовное право. Особенная часть: учебник для вузов. М., 2000. $501 \mathrm{c}$.

9. Гравина А. А. Преступления против мира и безопасности человечества // Уголовное право Российской Федерации: учебник / отв. ред. В. П. Кашепов. М.: Норма, 1999. 521 с.

10. Ожегов С. И. Толковый словарь русского языка / отв. ред. Л. И Скворцов. M.: ACT, 2020. 1360 c. 